\title{
References:
}

1. Gulay, O. I. (2016). Teoretichni ta metodichni osnovi profesijnoi pidgotovki majbutnix faxivcziv budivelnogo profilyu $v$ umovax neperervnoï osviti [Theoretical and methodological bases of professional training of future specialists of construction profile in the conditions of continuous education]. dis. dlya nauk. stupin kand. ped. Nauk: Specz. 13.00.04 «Teoriya ta metodika osviti profesora» Gulaj O. Hmelniczkij, 435 p.

2. Dudko, L. A. (2004). Rol innovaczijnix pedagogichnix texnologij u formuvanni konkurentospromozhnix faxivcziv [The role of innovative pedagogical technologies in the formation of competitive specialists]. Multivers Filosofskij almanax, no 39, pp. 78-84.

3.Zhilyaeva, Yu. M. (2008). Kategorichnij analiz ponyattya «proektnij metod» [Categorical analysis of the concept of «project method»]. Visnik Zhitomirskoi derzhavnij. un-tu. Pedagogichni nauki, no. 39, pp. 110-113.

4. Kozyar, M. M. (2004). Innovaczijni texnologii yak instrument orientovanogo na studentiv pidxodu u praktichnij pidgotovczi majbutnogo inzhenera [Innovative technologies as a tool of student-centered approach in practical training of future engineer]. New pedagogical thought, no. 1, pp. 90-93. URL: http://nbuv.gov.ua/ UJRN/Npd_2014_1_28

5. Kylpatryk, V. Kh. (1925). Metod proektov. Prymenenye tselevoy ustanovky $v$ pedahohycheskom protsesse [Method of projects. The application of the target setting in the pedagogical process]. L.: Brokhaus-Efron, 43 p.

\section{THE PREPARATION OF THE TEACHER OF LABOUR PROTECTION TO WORK IN VOCATIONAL COLLEGES}

\section{Tetiana Petrenko ${ }^{1}$}

DOI: https://doi.org/10.30525/978-9934-588-39-6-13

A teacher of labour protection is a person with higher education (pedagogical or special), has moral principles in relation to attitude toward colleagues and students, corresponding professional level in the conditions of educational process, due to in-plant training (each 5 in a volume 150 hours), has the proper physical and psychological health.

In the process of teaching disciplines: «Labour protection» from the teacher requires the following organization of the educational process:

1. The establishment of a working curriculum (based on the curriculum approved by the Ministry of education and science of Ukraine), the calendarthemed plan (in accordance with the load and work program).

\footnotetext{
${ }^{1}$ Open International University of Human Development «Ukraine», Ukraine
} 
2. Development of methodical instructions to performance of practical and laboratory work.

3. Registration of complex of instructions is for realization of instructing (introductory, primary, repeated, having a special purpose and not provided for by the plan).

4. Registration of magazines of registration of instructing.

The above-mentioned events are envisaged both during studies and at passing of all types of practice, that foresight in curricula for every level of preparation of students.

Every teacher, labour protection, needs to examine the state of teaching and the system of work of teacher by training and knowledge test on labor protection and safety on the basis of the «Main educational-methodical center Gastrula» or other educational establishments that are licensed for such activity, and the results of training a teacher receives an appropriate ID (the action ID 3 years).

In vocational educational establishments it is necessary to heave up all measures for providing of creation of safe terms of educational-educator process according to a current legislation, by inter-branch and other documents from a labour and safety of vital functions protection [1].

In accordance with a legislation [2] a teacher is:

1. Accountable for maintenance of life and health of bread-winners of education during an educational process.

2. Provides realization of educational process that is regulated by legislative and normatively-legal acts on questions a labour, safety of vital functions protection.

3. Organizes the study of formation of rules and norms bread-winners from a labour, safety of vital functions protection.

4. Conducts instructing with the bread-winners of education.

5. Carries out control after implementation of rules (instructions) breadwinners from safety.

6. Conducts prophylactic work in relation to prevention of traumatism among the bread-winners of education during an educational process.

7. Conducts prophylactic work among the bread-winners of education in relation to the requirements of the personal safety in the way of life.

8. At an offensive during the educational process of accidents takes measure envisaged normative documents.

Due to updating of methods of studies, the teacher of labour protection has the opportunity to realize an educational process through educational, educator, developing and professional to composition.

It follows to be also stopped for planning, organization, stimulation, to control and adjusting of every component of educational process on lecture, 
practical, laboratory, seminar employments, preparations of division «labour Protection».

To our opinion, the teacher of labour protection must always самовдосконалюватись through a self-education and self-education, selfknowledge, introspection and self-appraisal.

The value of activity of teacher of labour protection in an educational process is built on fundamental to mastering of new on-line tutorials, technologies and their realization; introduction of front-rank pedagogical experience.

The self-education of teacher of labour protection - it foremost the permanent process of acquisition of knowledge from the article of teaching and possibility of transmission, distribution of information to the students both in an audience and in the terms of independent preparation to the lessons.

The self-education of teacher of labour protection is determined as a process of permanent acquisition of ethic attitude toward all participants of educational process.

Self-knowledge of teacher of labour protection takes place through philosophical perception of educational process and individual robot with students.

An introspection in activity of teacher of labour protection shows up during realization of open employments, but with possibility of record of employment on a chamber, that on completion, to see the mimicry, gestures and rules of behavior.

A self-appraisal is a process of perception of criticism from the side of colleagues, and also ability to hear the estimation of students in relation to planning and conduct of lessons.

All above-mentioned processes fold the pedagogical competence of teacher of labour protection; promote to perfect professional knowledge and skills.

Thus, every teacher from a labour protection must responsibly behave to the discipline, as the proper knowledge, abilities and skills receipt students must use both during studies and practice and future work on speciality.

\section{References:}

1. Polozhennia pro orhanizatsiiu robot navchalnykh zakladakh, zatverdzhenoho nakazom Ministerstva osvity i nauky Ukrainy № 563 (2001). Retrieved from: https://zakon.rada.gov.ua/go/z0969-01

2. Polozhennia pro orhanizatsiiu roboty $\mathrm{z}$ okhorony pratsi ta bezpeky zhyttiediialnosti uchasnykiv osvitnoho protsesu $\mathrm{v}$ ustanovakh i zakladakh osvity № 1669 (2017). Retrieved from: https://zakon.rada.gov.ua/go/z0100-18 